\title{
DEVELOPMENT OF ANTIBODY TO RALSTONIA SOLANACEARUM AND ITS APPLICATION FOR DETECTION OF BACTERIAL WILT
}

\author{
YADI SURYADI \\ Bacteriology Laboratory, Department. of Biochemistry, ICABIOGRAD \\ Bogor 16111, Indonesia
}

\begin{abstract}
The serological assay for the detection of bacterial wilt caused by Ralstonia solanacearum (RS) was able to provide information regarding the presence of the pathogen in plant materials. The research is was aimed to develop polyclonal antibody (PAb) for RS detection. Bacterial whole cells of RS isolates mixed with glutaraldehyde were used to immunize New Zealand female white rabbit. The titre of antibody in culture supernatant was 1: 1024. The PAb developed from a ground nut RS isolates reacted with infected plant samples from various locations. It was able to detect RS antigen of crude extract and pure cultures from tomato and potato plant samples using dot blot ELISA; however, the minimum detectable concentration of RS antigen was $10^{4.5}$ cells $/ \mathrm{ml}$. The PAb obtained in this study is sensitive enough to detect RS isolates in routine serological assay.
\end{abstract}

Key words: Bacterial wilt, Ralstonia solanacearum, antibody, dot blot ELISA.

\section{INTRODUCTION}

It is known for a long time that bacterial wilt (BW) caused by Ralstonia solanacearum (Yabuuchi et al. 1995) (Syn: Pseudomonas solanacearum EF Smith) is one of the most destructive bacterial diseases of plants in tropical and subtropical regions of the world (Hayward 1991). The disease has a major economic importance as it can affect a wide range of food and cash crops such as tomato, potato, eggplant, groundnut and banana (Grimault \& Prior 1994). The bacteria can survive for long periods even in the absence of susceptible crops by association with many alternative weed hosts (Machmud 1985). BW disease can infect both the shoots and the roots of its hosts causing wilting symptoms of the stem and leaves. At first wilting of plants occurs on sunny days, but as infection progresses the wilting becomes permanent causing the leaves to dry out. $\mathrm{BW}$ disease also affects potatoes by causing it to rot, especially the tubers due to the accumulation of bacteria that exudates in the stolon end, and it may serves as a source of inoculums for subsequent planting, hence early detection and identification of the pathogen is crucial in an integrated disease management program through seed health testing program, plant quarantine inspection and identification of clean sites for planting. 
Successful control of BW disease needs an accurate detection, by using efficient and easy method for routine diagnostic test notwithstanding that early, rapid detection of RS in plant and soil is still lacking (Fegan \& Prior 2004). Pathogen of BW may infect a host plant without manifestation of causing symptom (latent infection). As a result, vegetative propagated plant materials such as seeds, tubers or suckers containing the pathogen may disseminate through domestic or internal exchange, therefore it is necessary to avoid such infected planting materials by subjecting it to quarantine and seed certification tests.

The traditional method for detecting BW pathogen relying on biochemical and pathogenicity test is tedious and time consuming that it may take up to 3 weeks to obtain the result. Several new diagnoses tests such as serological and molecular techniques are relatively easier and rapid to perform (Seal et al. 1993; Seal \& Elphinstone 1994; Fegan et al. 1998). Of those techniques, the serological technique displayed to be easy to use especially in an incomplete less equipped laboratory. A serological assay like ELISA shows effectiveness on account of its speed and high accuracy level (Alvarez et al. 1992). However, the adoption of those techniques in this country will depend on the availability of the antibodies and chemicals which are then of scarce supply and relatively expensive. Hence, the production of the specific antibodies suitable for Indonesian condition is still necessary to be introduced and applied in the domestic fields. Smith et al. (1995) reported the use of antibodies to detect RS in plant samples, and Whilst Van Vuurde et al. (1994) used immunofluorescense colony staining (IFC) method to detect Erwinia sp. on potato stem. Recently, Priou et al. (1998) at CIP-Peru developed a kit of nitrocellulose membrane (NCM)-ELISA or dot blot ELISA for BW detection using PAb. It was reported that the kit added with enrichment media, was able to detect RS samples.

In order to test sensitivity and specificity of PAb against BW, this paper reports the production of PAb to Indonesian RS isolates and describes the use of antibodies with dot blot ELISA test for rapid and sensitive detection of RS applicable for seed health testing and plant quarantine purpose.

\section{MATERIALS AND METHOD}

\section{Preparations of antigen of RS isolates, production and purification of antibody to $\mathrm{RS}$}

Plants with wilt symptoms were collected from Bogor areas like ground nut, Lembang (tomato), and Segunung (potato). Bacterial colonies were isolated from the infected plants and identified as RS biovar III based on the biochemical test (Hayward 1964). Bacterial isolates from infected ground nut plant (RS 9819; RS 9813), tomato (RS 50), and potato (RS 9750) were cultured in $9 \mathrm{~mm}$ plastic petridishes containing Tetrazolium chloride (TZC) agar medium at $28^{\circ} \mathrm{C}$ for 48 hour following the method of Smith (1994). The fluidal bacterial whole cells were harvested in sterile distilled water (SDW) and it was spun down at $8000 \mathrm{x} g$ for 15 minutes and washed three times using SDW. The pellets were resuspended in SDW and the concentration was checked by measuring it in a spectrophotometer using absorbance at $650 \mathrm{~nm}\left(\mathrm{OD}_{650 \mathrm{~mm}}\right)$ assuming 
that $\mathrm{Od}_{650 \mathrm{~nm}}=0.1$ was equivalent to $10^{7}$ cells $/ \mathrm{ml}$. The cells were adjusted to $10^{8}$ cells $/ \mathrm{ml}$ in $0.85 \%$ saline buffer, following the method of Klement et al. (1990). Aliquots of 0.5 $\mathrm{ml}$ were stored at $-20^{\circ} \mathrm{C}$ for long storage of RS antigen stock (RS control positive).

Four females New Zealand white rabbits ( \pm 3 month-old) were first injected intramuscularly with a total of $0.5 \mathrm{ml}( \pm 100 \mathrm{ug}$ of protein) cells antigen fixed with glutaraldehyde in $0.5 \mathrm{ml}$ sterile saline $1 \%$ solution that was emulsified in equal volume of Freund's complete adjuvant (FCA) following the protocol of Smith et al, (1995). Two weeks later rabbits were injected again with the antigen containing the same volume of Incomplete Freund's Adjuvant. Blood was extracted from the lateral ear vein with two-weekly interval (four times bleeding). The blood was allowed to settle at temperature $37^{\circ} \mathrm{C}$ for two hours, it was then separated by centrifugation at $3000 \mathrm{x} g$ for 10 minutes and the serum fraction was collected. The amount of antibody present in the serum (antibody titre) was determined either by ELISA test or agglutination method. The indirect ELISA was used to test antibody following the procedure of Smith et al, (1995). In agglutination test, the tubes were filled with PAb diluted to 10 fold in saline Phosphate buffer (PBS) pH 7.3. The bacterial suspension were decanted into each of the tube and then incubated at $37^{\circ} \mathrm{C}$ for 24 hours. The positive reaction was observed as cloudy suspension at the bottom of the tubes. Titre antibody was determined based on positive reading in the smallest dilution. The PAb was further partially purified using ammonium sulphate precipitation following the procedure of Bollag et al, (1996). After dialysis using Phosphate buffer pH 7.3, it was checked by spectrophotometer using absorbance $280 \mathrm{~nm}$ and $260 \mathrm{~nm}\left(\mathrm{OD}_{280 / 260 \mathrm{~nm}}\right)$ assuming that $\mathrm{OD}_{280 / 260 \mathrm{~nm}}=1.4$ is equal to amount of $1 \mathrm{mg} / \mathrm{ml}$ protein antibody.

\section{Screening of PAbs and detection of infected plant samples using dot blot ELISA}

Artificially inoculated and naturally infected plants (tomato, potato, ground nut) were screened for the presence of RS either using PAbs developed in Indonesian RS isolates or PAbs developed from UK, following the procedure described by Smith et al. (1995). Using slightly modified procedure, a nylon membrane (Boehringer Mannheim) was used to replace nitro cellulose. At least $20 \mu$ l bacterial suspension (antigen) in tris buffer sulphate (TBS) buffer $\mathrm{pH} 7.5$ were spotted on the surface of membranes. After coating for 1 hour at room temperature, the membrane were washed 3 times in tris buffer sulphate-tween (TTBS) containing TBS and 2\% tween 20. The membrane was blocked using blocking buffer (TBS + skim milk) for 1 hour. After washing step they were dropped with PAb diluted in blocking buffer (1:100, 1:400, 1:800 and 1:1000) and incubated overnight. Second antibody, a goat anti rabbit (GAR)conjugated to alkaline phosphatase (AP) was diluted in conjugate buffer (1:1000) and incubated for 1 hour. Finally, $30 \mathrm{ml}$ substrate buffer containing nitro blue tetrazolium bromochloroindolacetil phosphate (NBT/BCIP) was added into the membranes until sufficient color developed. The reaction was stopped by adding SDW. A positive reaction was observed qualitatively based on purple-blue spot on membranes. 


\section{RESULTS AND DISCUSSION}

In Indonesia, BW caused by RS that infect many economical crops is difficult to control. Previously, serological assay such as indirect ELISA had been successfully used to detect the pathogen from potato tuber seeds (Suryadi et al. 1998). The successful use of dot blot ELISA in detecting viral plant pathogen has also been reported to have reaction on sweet potato viruses (Manzila et al. 1997; Machmud et al. 2004).

Serum of antibody is generally obtained with high titre of $1: 1024$, while serum of antibody with a titre in excess of 1: 1600 was also obtained only after twoimmunization schedule. The reason might be on the level of immune response of the animal tested or non-specific protein binding sites. As pointed out by van Regenmortel (1992) yield of PAb varies depending on the animal tested. Using dilution and ELISA, Rajeshwari et al. (1998) reported that a good titre of $\mathrm{Ab}$ $(1: 10,000)$ was obtained after fourth test bleeding of rabbit. The titre of crude serum or PAb produced in this study which was also checked by indirect ELISA test (Smith et al, 1995) showed relatively high titres and reacted with RS antigen $\left( \pm 10^{8} \mathrm{cfu} / \mathrm{ml}\right)$ (Fig. 1). The absorbance reading ranged from 0.46 to 0.92 compared with that of negative control treatment (buffer/SDW). This titre was pooled and collected for partial purification using ammonium sulphate precipitation. Based on this purification, yield of antibody was slightly lower when it was read using spectrophotometer at wave length of $\mathrm{A}_{280 / 260 \mathrm{~nm}}$ ratio $(<1.4)$.

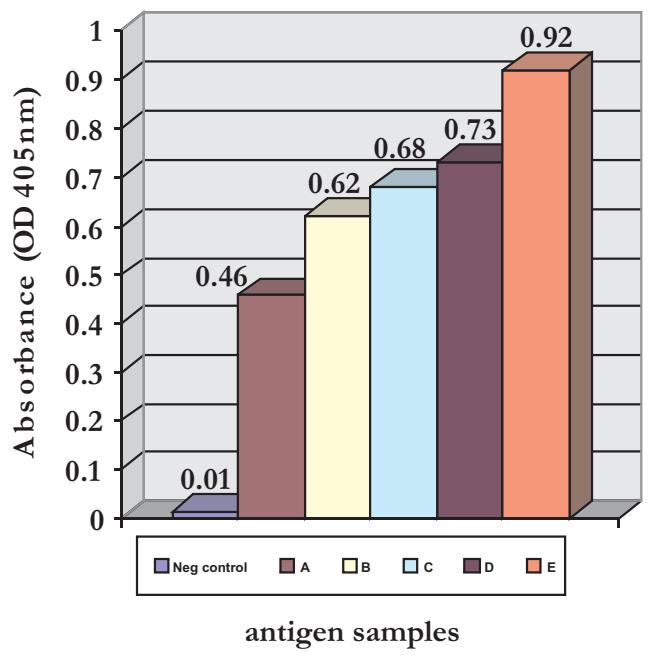
A. $10^{4} \mathrm{cfu} / \mathrm{ml}$
B. $10^{5} \mathrm{cfu} / \mathrm{ml}$
C. $10^{6} \mathrm{Cfu} / \mathrm{ml}$
D. $10^{7} \mathrm{cfu} / \mathrm{ml}$
E. $10^{8} \mathrm{cfu} / \mathrm{ml}$

Figure 1. Screening of serum to RS antigen samples based on indirect ELISA

Result of the study on producing PAb is presented in Table 1. Four PAbs to RS namely PAb-RS9819, PAb-RS50, PAb-RS9813, and PAb-RS9750 were raised in this study and the reactivity of PAbs-RS with various RS isolated from ground nut, tomato and potato was further determined based upon dot blot assay. 
Table 1. Screening of PAb against plant samples infected by RS from various locations, using dot blot assay.

\begin{tabular}{lcccc}
\hline \multicolumn{4}{c}{ PAb (dilution 1:500) } & \\
\multicolumn{1}{c}{ Plant samples/locations } & PAb-RS9819 & PAb-RS50 & PAb-RS9813 & PAb-RS9750 \\
\hline Ground nut- Cikeumeuh Bogor & +++ & - & - & ++ \\
Potato-Segunung & +++ & - & - & ++ \\
Tomato-Lembang & +++ & - & - & ++ \\
Negative control (buffer/SDW) & - & - & - & - \\
\hline
\end{tabular}

Remark: $+++=$ strong reaction, $++=$ moderate reaction, $-=$ no reaction

Using dilution of 1:500, PAbs of RS9819 and RS9750 showed positive moderate to strong reaction in RS detection. Two others PAbs shows showed negative or weak reaction to the RS samples. PAb raised from ground nut isolate RS 9819 (diluted at 1:1000) showed good comparable detection results, when compared with standard PAb (IACR-UK 322) received from UK (kindly provided by Dr. AR.. Smith) (Table 2). However, the level of detection was still low as it can only detect cells up to $10^{4.5}$ cells $/ \mathrm{ml}$. In the previous work, similar assay also showed suitable for detection of bacterial RS from various potato samples (Priou, 1998). In dot blot serological assay, the protein-binding ability of membrane was similar than that of the microtitre plates (Lazarovits et al, 1989). The comparative PAb IACR-UK RS-322 was previously effective in detection of potato tuber samples infected by latent infection of RS (Suryadi et al, 1998). A preliminary study indicated other PAbs developed at IACR-UK (RS-278, RS-356) that have been previously used in detection of plant samples infected by RS using indirect ELISA showed similar result, though these PAbs showed low level of detection on various Indonesian RS isolates (Suryadi, unpublished).

Table 2. Comparison of RS antigen preparations as detected by PAbs RS 9819 and IACR 322, using dot blot assay

\begin{tabular}{lcc}
\hline & PAb (dilution 1:1000) & \\
Samples antigen of RS & PAb-RS 9819 & LACR-UK 322 \\
\hline Whole cells & +++ & +++ \\
Pure culture & +++ & +++ \\
Negative control (buffer/SDW) & - & - \\
\hline
\end{tabular}

Remark: $+++=$ strong reaction, $-=$ no reaction

Figure 2 (A, B and C) represents reactivity of PAbs with various RS samples. Extract of the samples, containing plant extract (sap) and pure culture of RS extracted from diseased plant samples (infected by RS from various locations) could be detected as purple-blue spot on membrane. Neither cells nor culture filtrate of other bacterial species such as Xanthomonas oryzae pv oryzae (XOO), Psendomonas syringae pv. glycinea (PSG) and Xanthomonas campestris pv. glycinea (XCG) reacted with PAb-RS (Fig. 3). 


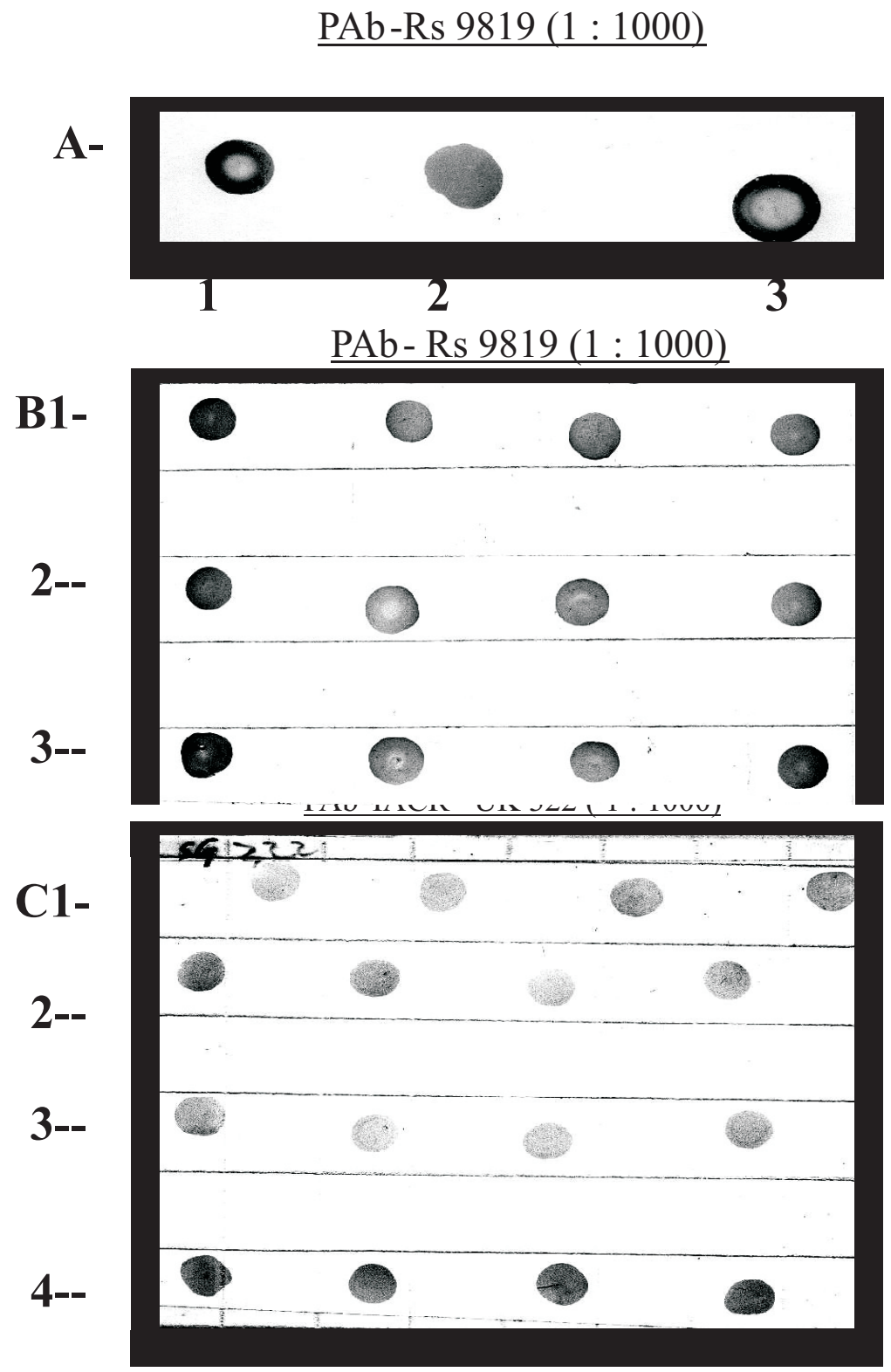

Figure 2. RS samples from various locations as detected using PAb-RS (1: 1000) and dot blot ELISA

A. No 1, 3= RS sample from pure extract of tomato and potato RS antigen detected by PAb-RS 9819; respectively. $2=$ RS sample from ground nut plant extract (Bogor) detected by PAb-RS 9819.

B. Row no $1=$ control positive, row no 2, $3=$ RS samples from tomato plant extract (Lembang) detected by PAb-RS 9819.

C. Row no $1=$ control positive, row no 2, 3, 4= RS samples from potato plant extract (Segunung) detected by PAb-IACR-UK 322. 


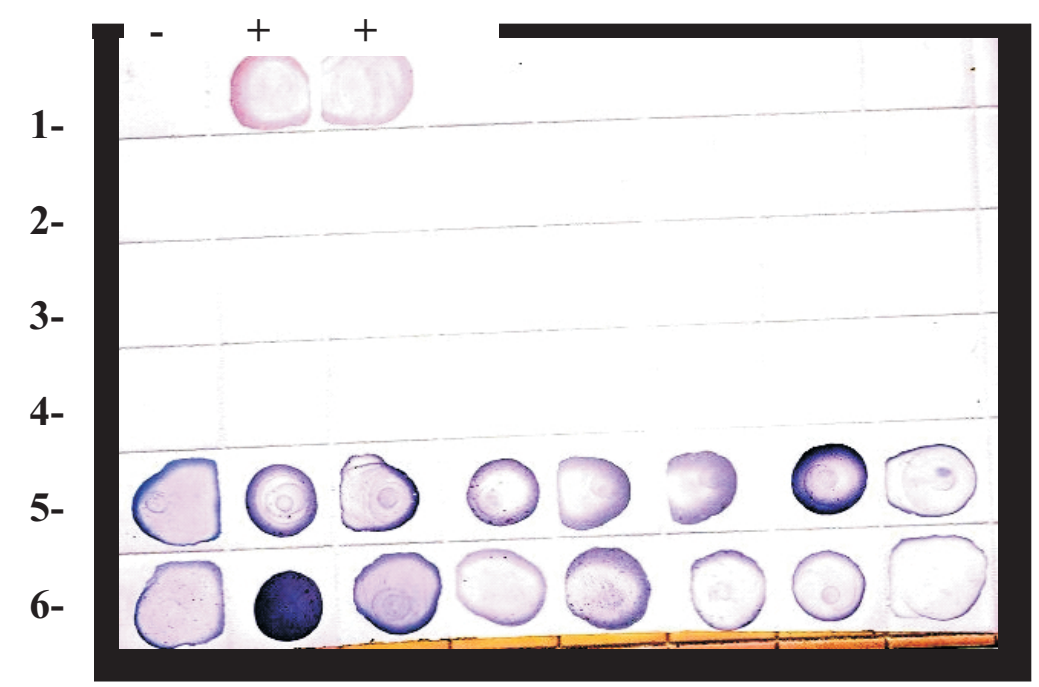

Figure. 3. Detection of RS from various bacterial cells antigen and RS antigen using PAb RS 9819 (1:1000). Number in row indicating samples. Row no $1=$ negative control/buffer (-) and positive control of RS $(+)$; row $2=$ Antigen XOO, row $3=$ Antigen PSG; row $4=$ Antigen XCG; rows 5, $6=$ indicating tomato and potato RS samples from Lembang infected by RS.

The desirable ELISA in routine seed health testing is relied on the specificity in the detection of the pathogen. Smith (1994) reported that ELISA by using MAb could not be as sensitive as the PAb. Glutaraldehyde fixation to produce antibody may cause disturbance of the structural bacterial component that could affect non strain/races species (Harlow \& Lane 1988); however, the PAbs produced in this study reacted not only with the bacterium to which they were raised but also with races of the pathogen. A research in UK showed that using indirect ELISA, PAb could detect RS but still unable to discriminate between RS and closely related bacteria such as Psendomonas picketii and P. cepasia (Smith et al. 1995). This cross reactivity would affect virus detection in soil samples when these pathogens are frequently present.

Application of the new developed PAb from local ground nut isolates in this study could serve as material stock for routine use in serological test by using dot blot ELISA, and large scale screening of antibody need to be carried out in order to provide low-cost effective PAbs in the region. In addition, since serological assay has the advantage of detecting the pathogen without the need for the pure culture, the technique could be employed for the rapid monitoring of pathogenic bacteria present in seed lots from commercial seed consignments, and for germplasms and seed testing in quarantine laboratory. 


\section{CONCLUSION}

The PAb raised from ground nut isolate (RS9819) showed effectiveness in detecting various plants like samples (ground nut, tomato and potato) infected by RS. The minimum detectable concentration of RS antigen was approximately $10^{4.5}$ cells $/ \mathrm{ml}$.

\section{ACKNOWLEDGMENT}

I would like to thank Mr. Wawan and Mrs. E. Windiyati for their technical assistance in preparing antigen and antibodies of RS. The polyclonal antibodies provided by Dr. AR Smith (IACR-UK, Rothamsted) are gratefully acknowledged. I would like also to express my sincerest thanks to Dr. M. Machmud for his critical reading of the manuscript.

\section{REFERENCES}

Alvarez A.M., Berestecky J., Stiles J.L., Ferreira S.A. and A.A. Benedict. 1992. Serological and molecular approaches for identification of P. solanacearum strains from Heliconia. ACIAR Proceedings No 45: 62-69.

Bollag D.M., Michael D.R. and J.E. Stuart. 1996. Protein methods $2^{\text {nd }}$ Ed. A John Willey and Sons, Inc. Pub., New York. p. 414.

Fegan M., Holoway G., Hayward A.C. and J. Timmis. 1998. Development of a diagnostic test based on the polymerase chain reaction (PCR) to identify strains of R. solanacearum exhibiting the biovar 2 genotype. In: Prior $e t$ al. (eds). Bacterial wilt disease molecular and ecological aspects: 34-43. Springer-verlag Berlin Heidelberg, New York.

Harlow E. and D. Lane. 1988. Antibodies, a laboratory manual. Cold Spring Harbor, New York.

Hayward A.C. 1964. Characteristics of P. solanacearum. Journal Applied Bacteriology, 27: 265-277.

Hayward A.C. 1991. Biology and epidemiology of bacterial wilt caused by P. solanacearum. Annual Review of Phytopathology, 29: 67-87.

Grimault V. and P. Prior. 1994. Invasiveness of R. solanacearum in tomato, eggplant and pepper: a comparative study. European Journal of Plant Pathology, 100: 259267.

Klement Z., Rudolph K. and D.C. Sand. 1990. Methods in phytobacteriology. Academiai, Kiado Budapest. p. 568.

Lazarovits G., Zutra D. and M. Bar-Joseph. 1989. Enzyme linked immunosorbent assay on nitrocellulose membranes (dot-ELISA) in serodiagnoses of plant pathogenic bacteria. Canadian Journal of Microbiology, 33: 98-103.

Machmud M. 1985. Bacterial wilt in Indonesia. Bacterial Wilt Workshop. PCARD, Los Banos Laguna, Philippines. p. 16.

Machmud M., Suryadi Y. and I. Manzila. 2004. Detection of sweet potato viruses in sweet potato germplasms from Irian Jaya. In: Hardaningsih et al. (eds). Proc. Teknologi inovatif agribisnis kacang-kacangan dan umbi-umbian untuk mendukung ketahanan pangan: 487-490. Puslitbangtan. Badan Litbang Pertanian.

Manzila I., Machmud M., Braun A. and S. Peter. 1997. Deteksi virus ubi jalar menggunakan teknik NCM-ELISA. p. 86-91. Risalah Kongres Nasional XIV PFI, Palembang.

Priou S. 1998. Manual for detection of R. solanacearum using the NCM-ELISA technique. CIP Lima Peru. 
Development of antibody to ralstonia solanacearum and its application - Yadi Suryadi

(Mimeograph).

Rajeshwari N., Shylaja M.D., Krishnappa M., Shetty H.S., Mortensen C.N. and S.B. Mathur. 1998. Development of ELISA for the detection of. R. solanacearum in tomato; its application in seed health testing. World Journal of Microbiology and Biotechnology, 14: 697-704.

Seal S.E., Jackson L.A., Young J.P.W. and M.J. Daniels. 1993. Differentiation of P. solanacearum, P. syzigii, P. pickettii and the blood disease bacterium by partial $16 \mathrm{~S}$ rRNA sequencing: construction of oligonucleotide primer for sensitive detection by PCR. Journal of General Microbiology, 139: 15871594.

Seal S.E. and J.G Elphinstone. 1994. Advances in identification and detection of P. solanacearum. In: Hayward A.C. and G.L. Hartmann (eds). Bacterial wilt the disease and its causative agent $P$ solanacearum: $35-57$. CAB Int. Wallingford, UK.

Smith R.A. 1994. Serological techniques for the detection of Pseudomonas solanacearum. In: Mehan V.K. and D. McDonalds (eds). Techniques for diagnosis of P. solanacearum and for resistance screening against groundnut bacterial wilt: 18-22. ICRISAT, Patancheru- India.

Smith RA, Jones P., Elphinstone J.G. and S.M.D. Forde. 1995. Production of antibodies P. solanacearum the causative agent of bacterial wilt. Food and Agriculture Immunology, 7: 67-69.

Suryadi Y., Machmud M., Rusmadi and M.A. Suhendar. 1998. Detection of P. solanacearum from latently infected potato tubers using ELISA and PCR techniques. Jurnal Biologi Indonesia, 2(3):142-149.

van Regenmortel. 1982. Serology and immunochemistry of plant viruses. Academic Press. p. 302.

van Vuurde, J.W.L., De Vries P.H.M. and M.M. Lopez. 1994. Colonization of potato stems by Erwinia sp. including in planta detection in stem sections with IFC after in situ enrichment in agar medium. p. 747753. Proceeding of $8^{\text {th }}$ International Conference Plant Pathogenic Bacteria. INRA, Versailles.

Yabuuchi E., Y. Kosako., I. Yano., H. Hotta. and Y. Nishiuchi. 1995. Transfer of two Burkholderia and an alcaligenes species to Ralstonia. gen. nov-proposal of Ralstonia pickettii (Ralston, Palleroni, and Doudoroff, 1973) comb.nov, Ralstonia solanacearum (Smith, 1896) comb.nov and Ralstonia eutropha (Davis, 1969) comb. nov. The Journal of Microbiology and Immunology, 39(11): 897-904. 